\title{
Is Economic Transition One of the Proximate Determinants of Nutrition Transition in Nepal?
}

\author{
Yagya Prasad Subedi1 ${ }^{*}$, Padam Simkhada², Bishwambher Pyakuryal ${ }^{3}$ \\ ${ }^{1}$ Division of Applied Health Sciences, University of Aberdeen, Aberdeen, UK \\ ${ }^{2}$ Centre for Public Health, Liverpool John Moores University, Liverpool, UK \\ ${ }^{3}$ Central Department of Economics, Tribhuvan University, Kathmandu, Nepal \\ Email: "yagya.subedi@abdn.ac.uk
}

Received 22 February 2016; accepted 11 April 2016; published 14 April 2016

Copyright (C) 2016 by authors and Scientific Research Publishing Inc.

This work is licensed under the Creative Commons Attribution International License (CC BY). http://creativecommons.org/licenses/by/4.0/

cC) (i) Open Access

\begin{abstract}
Background: Historically, the process of nutrition transition begins with changes in economic structures which move away from agrarian economies to successful industrialisation, with high economic growth, urbanisation and increased real per capita income. Objective: The objective is to identify where Nepal is in economic transition and whether economic transition is considered as one of the proximate determinants of nutrition transition in Nepal. Results: Nepal's position in the economic transition has been identified by using Popkin's framework which is scaled from Pattern I to Pattern V. The time series trends indicated that new patterns of economic transition had been observed during 1995-2010, which was similar to the pattern IV of the Nutrition Transition as described by Popkin. The national income of Nepal increased over the past four decades. The GDP of Nepal has shown an annual increase at a rate of 3.92 per cent between 1970 and 2010. Conclusion: Economic growth and agricultural trade liberalization have induced plant fats supply in Nepal. Tourism has also transferred the taste and preferences of western foods to tourist destinations and urban centres, including potential negative health consequences related to excess consumption of fat, sugar and process foods.
\end{abstract}

\section{Keywords}

Economic, Nutrition, Food, Fat, Transition, Tourism, Nepal

\section{Introduction}

The agricultural revolution brought profound changes in food production and food storage, and the industrial "Corresponding author.

How to cite this paper: Subedi, Y. P., Simkhada, P., \& Pyakuryal, B. (2016). Is Economic Transition One of the Proximate Determinants of Nutrition Transition in Nepal? Open Journal of Political Science, 6, 168-178. 
revolution in developed countries over the last 200 years introduced radical changes in methods of food production, processing, storage and distribution (WB, 1993). Economic development is normally accompanied by improvements in a country's food supply and the gradual elimination of dietary deficiencies, thus improving the overall nutritional status of the country's population (FAO, 2010). Economic and technological developments also bring about improved quality in the production, processing, distribution and marketing of foods.

Historically, the process of nutrition transition begins with changes in economic structures which move away from agrarian economies to successful industrialisation, with high economic growth and increased real per capita income (World Bank, 2000; Popkin, 1993). After World War II, large shifts occurred in urbanisation, migration, production technology, employment patterns and productivity, and accelerated change in real per capita income, as well as the expansion of food choices (World Bank, 2000).

\section{Rational for the Study}

A considerable amount of literature has been published on the economic and nutrition transition in developing countries. These studies have indicated that economic, technological and nutrition transition is underway and rapid in such countries, with the simultaneous co-existence of undernutrition and obesity (Popkin, 2001). However, patterns and trends of economic transition in Nepal are changing. It is speculated that the process of economic transition in Nepal began during the 1980s and 1990s following the decision to open the economy for globalisation and agricultural trade liberalisation (Pyakuryal, Thapa, \& Roy, 2005; NPC/N, 2010). In particular, this study addressed the following research questions: Is Nepal a country in economic transition? Where is it in each stage of the economic transitions? What explanation is associated with these transitions?

\section{Objectives}

The specific objectives for identifying the economic transition in Nepal are the following:

1) To identify the time series trends of national per capita income, economic structure, per capita tourism revenue, prices of plant/animal fats, and food/livestock productions to explain where Nepal was in the economic transition over the past 40 years

2) To indicate where is Nepal in the economic transition within the Popkin’s framework of the Nutrition Transition.

\section{Data and Methods}

This study adopts Popkin's methodology for the identification of economic transition. There are 10 proxy foci identified by Popkin to describe the Nutrition Transition, which are grouped into four categories-economic, demographic, dietary and epidemiological transitions, for the purposes of this analysis. Economic variables include three proxies-they are national income, the economic structure and relative prices of plat sources and animal sources of foods (Table 1). Tourism is also included in the proxies of the Nutrition transition as a unique trigger of the Asian region. Globally considered proxies for economic transition are the overall growth in Gross Domestic Product (GDP) per capita; changes in the contributions of economic sectors namely agriculture, industry and services in GDP; changes in the proportion of urban population to total population; changes in the per capita tourism revenue; a relative prices of plant oils and animal fats; and changes in relative indexes of food/ livestock supply.

Although time series data generally exhibit random fluctuations, a time series may also show gradual shifts or movements to relatively higher or lower values over a longer period of time. If a time series plot exhibits this type of behaviour, we say that a trend pattern exists. A trend is usually the result of long-term factors such as income increases or decreases, changing demographic characteristics of the population, technology, and/or consumer preferences, etc.

The average annual percentage of change/growth of economic proxy variables for the period of forty years starting from 1970 to 2010 has been computed using two methods. The first one is annual growth rate method hat that would take the country from first year's level to the last. The formula for the average growth/change rate adopted for the computation is $=\left\{100 *(<\text { final value }>/<\text { initial value }>)^{\wedge}(1 /<\right.$ number of years' growth- $\left.1>)\right\}-100$ $[\mathrm{Or}=\{(1 /$ time period- 1$)$ natural logarithm $(\ln )(<$ final value $>/<$ initial value $>)\} * 100]$.

The second one is ordinary least squares trend line plotting method to predict the annual rate of growth for the exponential time line equation, which is minimizes the sum of squares of the difference between actual time series 
Table 1. Proxy foci, explanatory variables and data sources.

\begin{tabular}{ccc}
\hline Proxy Foci & Explanatory variables & Data sources \\
\hline Income & GDP per capita & Economic Surveys, Ministry of Finance \\
Economy & $\begin{array}{c}\text { Contribution of economic sectors } \\
\text { (Agriculture, Industry \& Services) }\end{array}$ & Economic Surveys, Ministry of Finance \\
Tourism & Per capita tourism revenue & Tourism Statistics, Ministry of Tourism, Nepal \\
Relative prices & Plant oils and animal fats & Economic Indicators, Central Bank of Nepal \\
\hline
\end{tabular}

data and predicted time series data. Therefore, the estimated trend line is fitted best to capture the real trend of the past 40 years.

The various proxies of economic trends are described one by one in the different sub-sections based on the results derived from above two methods of growth/change and timeline equations.

\section{Literature Review}

East Asia's near tripling of real income per capita during the last 30 years is one of the most extraordinary economic phenomena of this century (WB, 1993). Never before has income per capita grown so rapidly in such a large group of countries for such a prolonged period.

Numerous studies have sought to explain East Asia's economic "miracle". The literature highlights a wide range of possible explanations, including trade and industrial policies, technological progress, savings and capital accumulation, governance, education and health spending, geography and culture, and initial income levels (ADB, 2009).

Economic growth in general and East Asia's unrivalled growth performance in particular, is not a monocausal phenomenon (ADB, 1997). Economic growth is affected by many factors, whose cumulative effects can account for much of East Asia's superior performance in relation to that of the world economy as a whole during 1965-90, as well as for the relatively poor performance of South Asia and Sub-Saharan Africa (WB, 1993).

The literature is the generally superficial attention it pays to the influence of demographic factors on economic growth (ADB, 1997). In recent years, investigators have revisited the connection between population and economic growth, emphasizing the demographic transition as the process underlying population growth in most developing countries (Bloom \& Canning, 1999).

As the population age distribution changes over the course of a demographic transition and beyond, levels of income per capita will change correspondingly, revealing patterns of economic growth that have proven to be robustly evident in cross-national data (Bloom \& Freeman, 1986). Age structure is not the only influence on economic growth, but it certainly emerges as one of the most potent influences (WB, 1993). Asia registered impressive gains during this period as measured in terms of the growth of output per worker in all sectors. At the same time, it shifted from being predominantly an agrarian region to one with rapidly expanding industrial and service sectors (Krugman, 1994). South Asia and Southeast Asia are still primarily agricultural, although the signs of the start of their transformation into industrial and service-based economies are apparent (ADB, 1997). The industrial sector is by far the most productive in terms of output per worker, which is likely to be due to its higher levels of capital per worker (Bloom and Freeman 1997).

Labour productivity increased sharply in Asia during 1970-90, substantially more than in Latin America and in Sub-Saharan Africa (ADB, 1997). However, the differences across regions of Asia are significant: while labour productivity increased substantially in all major economic sectors in East and Southeast Asia, in South Asia labour productivity increased only slightly in each sector during the period (Bloom \& Sachs, 1998).

From 1970 to 1990 the labour force participation rate increased only slightly throughout Asia (WB, 1993). The ratio of the working-age population to the total population also increased as a result of the region's demographic transition (Bloom \& Sachs, 1998). The labour force increased at a more rapid rate than the working-age population, that is, a higher share of people of working age participated in the formal labour market in 1990 than in 1970. At the same time labour productivity increased across all sectors (Bloom \& Freeman, 1986).

Demographic variables have played a large role in East Asia's economic success. Increases in life expectancy have had a large effect on incomes in East Asia. A rapid decline in fertility, induced partly by the region's economic success, led to a substantial reduction in the youth dependency ratio, thereby helping to boost growth rates of income per capita (Bloom \& Canning, 1999). 
Economic growth in East Asia will likely slow in the future, because of stabilization of fertility rates at their current low levels and increases in the dependency ratio as the population ages. By contrast, Southeast Asia appears primed for an acceleration of long-run economic growth driven by increasingly favourable demographics (ADB, 1997). The working-age share of the population (which is also reflected in the ratio of working-age to non-working-age population) is a crucial indicator of a region's or countries potential for reaping a demographic dividend (UN, 2009).

South Asia has experienced a varying, but generally increasing, annual average growth rate in per capita gross domestic product (GDP), beginning at 1.9 per cent in 1960-70, falling to 0.6 per cent in the next decade, rising to 3.2 per cent for each of the next two decades, and climbing to 5.3 per cent since 2000. However, beginning in the 1970s, these rates are well below the corresponding figures for China (Judith, Bloom and Rosenberg, 2011). South Asia's relatively slow rate of economic growth has resulted in its GDP per capita falling progressively behind that of Brazil, China, and Indonesia (Bloom, Canning, \& Rosenberg, 2010).

The countries of the region have followed a somewhat more varied pattern, with Bangladesh and India matching the regional pattern most closely. Sri Lanka avoided the 1970s South Asian dip in economic growth rate, but now lags behind the region as a whole, with a rate of 4.0 per cent since 2000. Pakistan grew faster than the region through 1985, but has since seen slow growth (averaging 2.4 per cent since 2000). Nepal has languished during the entire period since 1960 (Bloom, Canning and Rosenberg). Historical data for Afghanistan, Bhutan, and the Maldives are spotty, but the latter two economies have done reasonably well since 2000 (Bloom, Canning, \& Rosenberg, 2010).

The correspondence between increasing GDP per capita and the rising ratio of working-age to non-workingage people is striking. For South Asia the general rising pattern of economic growth in the region since the 1960s corresponds, albeit roughly, to the increasing ratio of working-age to non-working-age people. If the correspondence between demographic opportunity and economic realization of that opportunity continues to hold, the projected rise in the ratio of working-age to non-working-age individuals suggests that South Asia will have a bright economic future (Bloom, Jeffery, \& Williamson, 1998).

Indeed, South Asia is projected to add an average of 18 million people to its working-age population every year for the next two decades - and the result will be a very high ratio of working-age to non-working-age individuals, which will peak in 2040 at 2.2:1. This ratio augurs well for future economic growth (UN, 2009). Smaller families may cause female labour-force participation rates to rise from their currently low levels. All of this growth in the size of the labour force can impel economic growth if working-age people participate in the economic activities (Sachs, 2015).

The availability of appropriately skilled people may not be sufficient to impel economic growth. If governments are to capitalize on the high share of working-age people in the population, they will have to ensure that those people are healthy, well educated, and well trained in the skills demanded by the labour market (UN, 2009). Tracking such an agenda fits very well with what many governments seek to do, even in the absence of a potential demographic dividend (Sachs, 2015). However, the dividend, which is a time-bound opportunity, may give policymakers incentive to redouble their efforts to promote the skills of the working-age cohort so that it has the ability to contribute productively to the economy (UN, 2009).

A high share of working-age people is beneficial only if those people are employed. If they are unemployed, the outcome will likely be problematic. Labour market policies must encourage employment. Sound macroeconomic management is key. An economy that has persistently high inflation is unlikely to be able to take the best possible advantage of a large segment of working-age people (UN, 2009).

Government institutions face a wide array of challenges. If governments are not up to the tasks they face-of providing infrastructure and other public goods and a legitimate and efficient policy environment, and addressing income and social inequality—a potential demographic dividend may be squandered (Bloom, Jefery, \& William, 1998). But full realization of the demographic dividend depends on the policies countries choose and on their political and economic relations with each other and the rest of the world (UN, 2009).

Travel \& Tourism is an important economic activity in most countries approximately the world. As well as its direct economic impact, the industry has significant indirect and induced impacts. The direct contribution of Travel \& Tourism to GDP reflects the "internal” spending on Travel \& Tourism (total spending within a particular country on Travel \& Tourism by residents and non-residents for business and leisure purposes) as well as government "individual” spending-spending by government on Travel \& Tourism services directly linked to visitors, such as cultural (e.g. museums) or recreational (e.g. national parks). 
The direct contribution of Travel \& Tourism to GDP is calculated to be consistent with the output, as expressed in National Accounting, of tourism-characteristic sectors such as hotels, airlines, airports, travel agents and leisure and recreation services that deal directly with tourists. The direct contribution of Travel \& Tourism to GDP is calculated from total internal spending by "netting out" the purchases made by the different tourism sectors (WTTC, 2008).

The total contribution of Travel \& Tourism includes its "wider impacts" (i.e. the indirect and induced impacts) on the economy. The indirect contribution includes the GDP and jobs supported by ravel \& Tourism investment spending - an important aspect of both current and future activity that includes investment activity such as the purchase of new aircraft and construction of new hotels. Another indirect contribution of tourism would be the government collective spending, which helps Travel \& Tourism activity in many different ways such as tourism marketing and promotion, aviation, administration, security services, resort area security services, resort area sanitation services, etc., domestic purchases of goods and services by the sectors dealing directly with touristsincluding, for example, purchases of food and cleaning services by hotels, of fuel and catering services by airlines, and IT services by travel agents (WTTC, 2008).

The induced contribution measures the GDP and jobs supported by the spending of those who are directly or indirectly employed by the Travel \& Tourism industry (WTTC, 2013). The direct contribution of Travel \& Tourism to Nepalese GDP in 2012 was NPR67.2bn (4.3 per cent of GDP). This is forecast to rise by 7.3 per cent to NPR72.2bn in 2013. This primarily reflects the economic activity generated by industries such as hotels, travel agents, airlines and other passenger transportation services (excluding commuter services). But it also includes, for example, the activities of the restaurant and leisure industries directly supported by tourists.

The total contribution of Travel \& Tourism to GDP (including wider effects from investment, the supply chain and induced income impacts, was NPR147.2bn in 2012 (9.4 per cent of GDP) and is expected to grow by 7.4 per cent to NPR158.2bn ( 9.80 per cent of GDP) in 2013. It is forecast to rise by 4.5 per cent pa to NPR245.6bn by 2023 (11.00 per cent of GDP). Travel \& Tourism generated 553,500 jobs directly in 2012 (3.6 per cent of total employment) and this is forecast to grow by 7.0 per cent in 2013 to 592,500 (3.8 per cent of total employment) (WTTC, 2013). This includes employment by hotels, travel agents, airlines and other passenger transportation services (excluding commuter services). It also includes, for example, the activities of the restaurant and leisure industries directly supported by tourists (WTTC, 2013).

The total contribution of Travel \& Tourism to employment (including wider effects from investment, the supply chain and induced income impacts, see page 2) was 1,255,500 jobs in 2012 (8.20 per cent of total employment). This is forecast to rise by 7.10 per cent in 2013 to 1,344,500 jobs (8.50 per cent of total employment) (WTTC, 2013). Visitor exports are a key component of the direct contribution of Travel \& Tourism. In 2012, Nepal generated NPR36.6bn in visitor exports. In 2013, this is expected to grow by 2.10 per cent, and the country is expected to attract 946,000 international tourist arrivals. Travel \& Tourism is expected to have attracted capital investment of NPR12.5bn in 2012. This is expected to rise by 8.20 per cent in 2013 (WTTC, 2013).

Leisure travel spending (inbound and domestic) generated 79.60 per cent of direct Travel \& Tourism GDP in 2012 (NPR84.8bn) compared with 20.40 per cent for business travel spending (NPR21.7bn). Leisure travel spending is expected to grow by 6.60 per cent in 2013 to NPR90.4bn, and rise by 4.40 per cent pa to NPR139.1bn in 2023. Business travel spending is expected to grow by 9.30 per cent in 2013 to NPR 23.7bn (WTTC, 2013). Domestic travel spending generated 65.70 per cent of direct Travel \& Tourism GDP in 2012 compared with 34.30 per cent for visitor exports (i.e. foreign visitor spending or international tourism receipts) (WTTC, 2013).

Most importantly, tourism is also identified as the key culturally influencing trigger to bring about social and dietary change (Lang, 1999). Tourism encourages the transfers of tastes and preferences from developed to developing countries through tourism interventions. Tourism penetrates the cultural traditions of middle class households leading to the changes in patterns of eating and local traditions (Cwiertka \& Walraven, 2002).

\section{Results}

\subsection{The Growth of GDP Per Capita}

The national income of Nepal increased over the past four decades. The GDP ${ }^{1}$ of Nepal has shown an annual in-

${ }^{1} \mathrm{MoF} / \mathrm{N}$ definition of GDP: "GDP is at constant 2005 US dollars. GDP is the sum of gross value added by all resident producers in the economy plus any product taxes and minus any subsidies not included in the value of the products. It is calculated without making deductions for depreciation of fabricated assets or for depletion and degradation of natural resources". 
crease at a rate of 3.90 per cent between 1970 and 2010. The population has also grown rapidly at a rate of 2.30 per cent per annum. The overall GDP per capita (at constant US \$ 2005) was 145 in 1970 and increased to 269 in 2010, at an annual growth rate of 1.50 per cent.

The time series trend line of GDP per capita in constant 2005 US \$ computed from least squares trend line plotting method shows that it explains the 96.37 per cent of reality $\left(\mathrm{R}^{2}=0.96366\right)$. The real annual rate of growth of trend line is 1.89 per cent (Figure 1). This is the trend line equation in the graph indicates that the real GDP per capita over the period of time was increased by approximately two per cent per year, but there are two distinct patterns in the periods before and after 1990. The growth rate of GDP per capita constant US \$ before 1990 was slower than after 1990.

Nepal's average real GDP per capita growth of past forty years was 1.55 per cent, which is lower than India, Pakistan and Sri Lanka (Table 2), but it is higher than Bangladesh and closer to the level of Pakistan.

\subsection{Economic Sectors/Structure}

The three main economic sectors contributing to the GDP in Nepal are Agriculture, Industry, and Services. The Nepalese economy has traditionally been agrarian in nature. In 1970, the Agriculture sector was the highest contributor (59.50 per cent) to the economy, which dropped to 35.80 per cent in 2010. In 1970, Industry contributed only 10.10 per cent, which rose to 18.20 per cent in 2010. The highest contributor to GDP in 2010 was the Service sector, which increased from 30.20 per cent to 45.90 per cent. The Agriculture Sector (value added in constant US dollar) has expanded by annual an annual growth rate of 2.60 per cent whereas Industry and Services sectors (value added in constant US dollar) have expanded by an annual rate of 5.40 per cent and 5.00 per cent respectively.

The structure of Nepalese economy has been changing. The industry sector has grown at average annual rate of 5.40 per cent in the first position, while the services sector is also growing at average annual rate of 5.00 per cent following the industry sector in the second position. However, the agriculture sector has just grown at average annual rate of 2.60 per cent. The agriculture sector's share on GDP was 59.60 per cent in 1970 and reduced to 35.90 per cent in 2010. Similarly, the industry sector's share on GDP was 10.20 per cent in 1970 and reached at 18.20 per cent in 2010. However, the services sector's share in GDP was 30.30 per cent in 1970 and reached at 46.00 per cent in 2010.

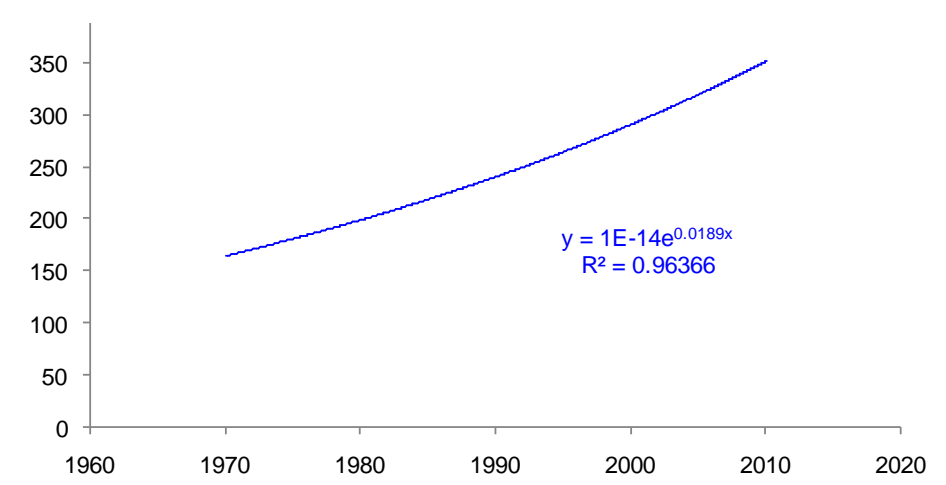

Figure 1. Trend of GDP per capita (constant 2005 US \$) in Nepal.

Table 2. Comparison of GDP per capita.

\begin{tabular}{cccc}
\hline Per capita GDP in 2005 dollars & $\mathbf{1 9 7 0}$ & $\mathbf{2 0 1 0}$ & Annual growth rate (\%) \\
\hline Bangladesh & 270 & 457 & 1.32 \\
India & 214 & 714 & 3.06 \\
Nepal & 145 & 269 & 1.55 \\
Pakistan & 285 & 687 & 2.22 \\
Sri Lanka & 338 & 1190 & 3.20 \\
\hline
\end{tabular}


The time series trend line of agriculture sector value added in national income in constant US \$ 2005 computed from least squares trend line plotting method show that the trend line explains approximately 98.00 per cent of reality $\left(\mathrm{R}^{2}=0.9763\right)$. The real annual rate of growth of agriculture sector is 2.79 per cent (Figure 2). The trend line equation in the graph indicates that the real value added of agriculture was increased by approximately 3.00 per cent per year, but there are two distinct patterns in the periods before and after 1990. The growth rate of agriculture sector before 1990 was faster than after 1990.

The time series trend line of industry sector value added in national income in constant US \$ 2005 computed from least squares trend line plotting method show that the trend line explains approximately 98.00 per cent of reality $\left(\mathrm{R}^{2}=0.9698\right)$. The real annual rate of growth of industry sector is 6.49 per cent (Figure 2). The trend line equation in the graph indicates that the real value added of industry sector was increased by approximately 7.00 per cent per year, but there are two distinct patterns in the periods before and after 1990. The growth rate of industry sector before 1990 was slower than after 1990.

The time series trend line of services sector value added in national income in constant US \$ 2005 computed from least squares trend line plotting method show that the trend line explains approximately 99.00 per cent of reality $\left(\mathrm{R}^{2}=0.9892\right)$. The real annual rate of growth of services sector is 4.68 per cent (Figure 2). The trend line equation in the graph indicates that the real value added of services was increased by approximately five per cent per year but there are two distinct patterns in the periods before and after 1990. The growth rate of services sector before 1990 was slower than after 1990.

\subsection{Tourism Inflows and Per Capita Tourists Expenditure}

The number of international tourists in Nepal has increased by an annual rate of 5.00 per cent between 1990 and 2010. But the tourism income increased by an annual rate of 3.20 per cent only. The annual growth rate of the arrival of international tourist was 4.60 per cent per year in the past forty years.

The time series trend line of tourists arrival computed from least squares trend line plotting method show that the trend line explains only 39.00 per cent of reality $\left(R^{2}=0.3900\right)$. The real annual rate of growth of arrival of tourists is 1.5 per cent (Figure 3 ). The trend line equation in the graph indicates that the arrival of tourists increased by approximately 1.50 per cent per year, but there are two distinct patterns in the periods before and after 1990. The growth rate of the arrival of the tourist before 1990 was slower than after 1990. Because of the low value of $\mathrm{R}^{2}$, the goodness fit of the trend line with the residuals seems to be weak to explain the reality.

The time series trend line of per capita tourist expenditure computed from least squares trend line plotting method shows that the trend line explains approximately 91.19 per cent of reality $\left(\mathrm{R}^{2}=0.9119\right)$. The real annual rate of decrease of per capita tourist expenditure is -5.77 per cent (Figure 3 ). The trend line equation in the graph indicates that approximately six per cent per year decreased the per capita tourist expenditure. The reason of decreasing rate of per capita tourist expenditure, even in the situation of increasing number of tourist arrival, may be either because of decreasing length of stay of the tourist or Nepal may be developed as a cheap tourists' destination.

\subsection{Urbanization and Population Dynamics}

The average annual growth rate of population in Nepal was 2.30 per cent for the past forty years. The average

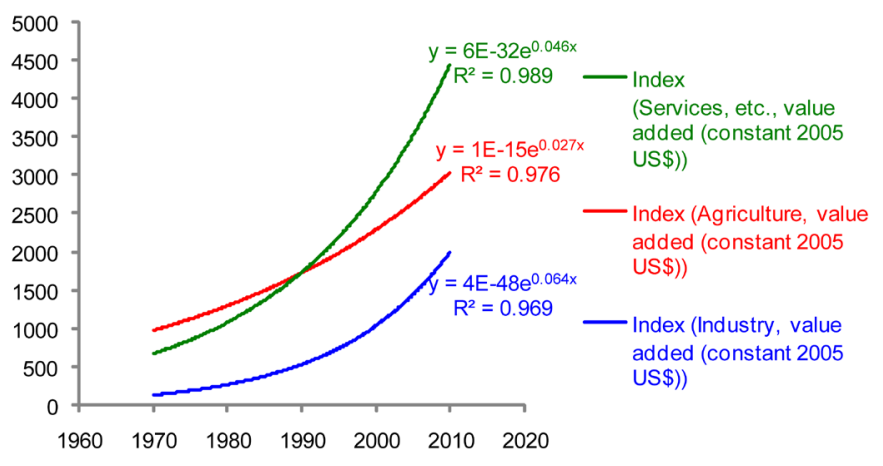

Figure 2. Changes in the economic structure in Nepal. 
Number of tourist and tourism revenue in Nepal

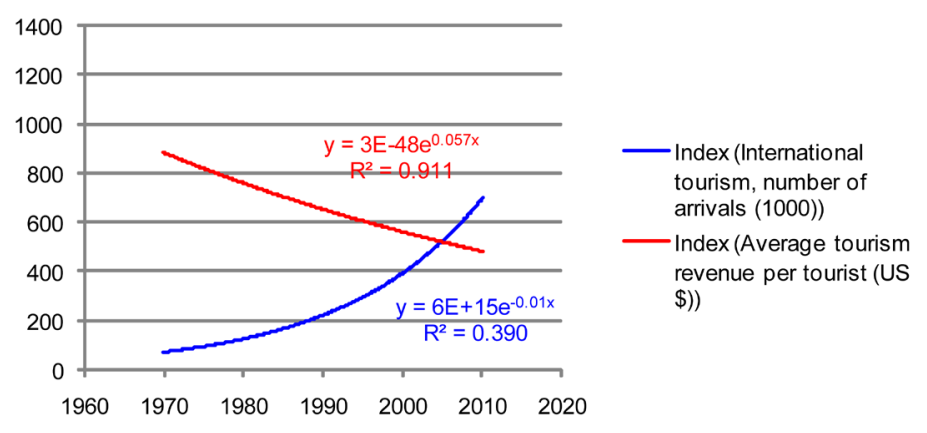

Figure 3. Tourist arrival and per capita tourism revenue in Nepal.

annual growth rate of urban population was 6.30 per cent whereas average rural population growth rate was just 1.90 per cent. The urban population in Nepal is expanded three folds in the past four decades, but the total fertility rate of rural women (4.3 births) was still quite higher than urban women (2.5 births) in 2011.

The time series trend line of total population $\left(\mathrm{R}^{2}=9995\right)$, rural population $\left(\mathrm{R}^{2}=0.9972\right)$ and urban population $\left(\mathrm{R}^{2}=0.9988\right)$ computed from least squares trend line plotting method show that these trend lines explains approximately 99.95 per cent of reality. The real annual rate of growth of urban population is 6.25 per cent. The trend line equation in the graph indicates that the urbanization in terms of urban population was increased by more than six per cent per year (Figure 4). The trend lines clearly indicate that the period before and after 1990 has distinctly two different patterns. The urbanization process was slower before 1990 and became faster after 1990, but the growth of total population (2.36 per cent) and rural population (1.96 per cent) are uniform through out the 40 years period.

The total labour force (in thousands) of Nepal had been double from 9376 in 1990 to 16,040 in 2010 with the average annual growth rate of 2.72 per cent. The female labour force was growing by average annual rate of 2.96 per cent, which is higher than the average male labour force growth rate.

The time series trend line of total labour force in Nepal computed from least squares trend line plotting method shows that the trend line explains approximately 99 per cent of reality $\left(R^{2}=0.9996\right)$. The real annual rate of growth of current labour force in Nepal is 2.68 per cent. The trend line equation in the graph indicates that the labour force in Nepal was increased by approximately three per cent per year throughout the period of the past 40 years (Figure 5). There are not clear distinctions in the patterns in the trend line of labour force growth within the forty years period.

\subsection{Relative Prices}

Food production index is grown by annual growth rate of 3.10 per cent; and the food supply (export and import adjusted) index is grown by annual average growth rate of 1.00 per cent in the past 40 years in Nepal. The annual population growth is 2.30 per cent per year; however, the average annual growth rate of food supply is 1.00 per cent. This may indicate that there is excess demand of food commodities in Nepal over the past decades which is stimulating upward pressure to the prices and creating inflationary situation in Nepal.

The average annual increase in the relative prices of selected commodities for example buffalo meat, pig meat, soybean and mustard oils are less than the average annual rate of inflation. This indicates that real prices of plant oils and animal fats are not increased.

The time series trend line (Phillips \& Perron, 1988) of the prices of mustard $\left(R^{2}=0.6305\right)$ and soybean $\left(R^{2}=\right.$ 0.7200) seeds computed from least squares trend line plotting methods show that the trend line explains approximately 63.05 per cent to 72.00 per cent of reality. The real annual rate of growth of the price of plant sources of oils in Nepal is three per cent (Figure 6). The trend line equation in the graph indicates that the mustard and soybeans prices in Nepal were increased by approximately three per cent per cent per year throughout the period of the past 20 years. There are not clear distinctions in the patterns in the trend line of these growths within the twenty years period.

The time series trend line of the prices of buffalo $\left(R^{2}=0.7502\right)$ and pig $\left(R^{2}=0.6344\right)$ meats computed from least squares trend line plotting methods show that the trend line explains approximately 75.02 per cent and 63.44 per cent of reality. The real annual rate of growth of the prices of buffalo and pig meats in Nepal are 2.87 


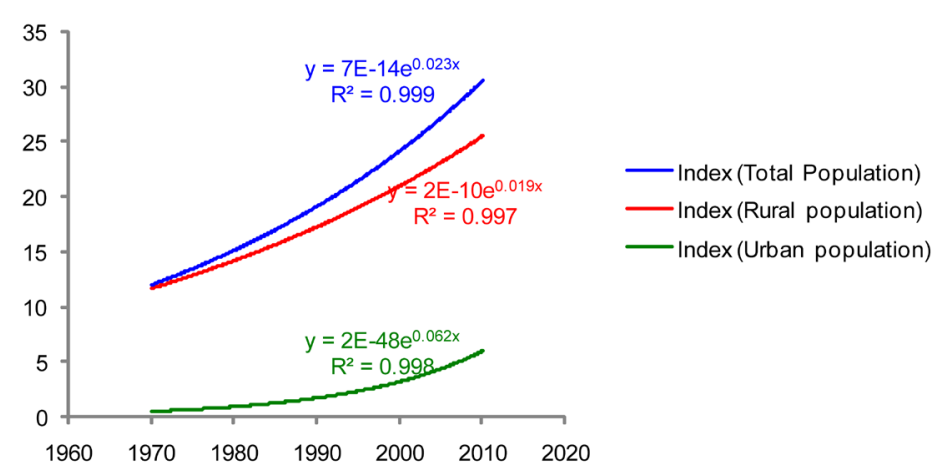

Figure 4. Urbanization and population dynamics in Nepal.

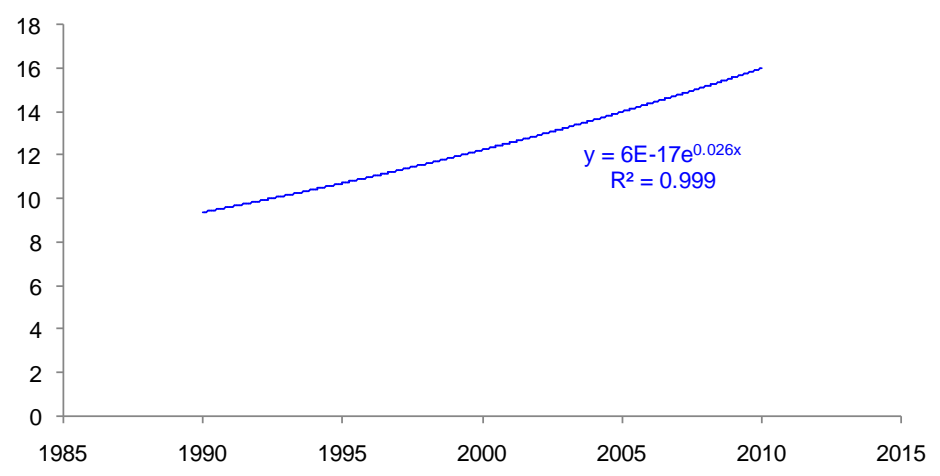

Figure 5. Current labour force, Nepal.

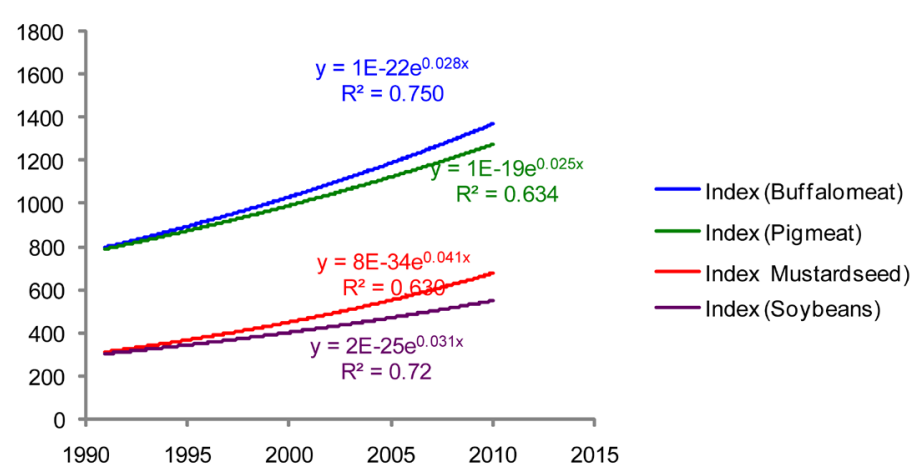

Figure 6. Prices of animal and plant meat/fat (US \$ per metric tons).

per cent and 2.52 per cent (Figure 6). The trend line equation in the graph indicates that the mustard and soybeans prices in Nepal were increased by approximately three per cent per year throughout the period of the past 20 years. There are not clear distinctions in the patterns in the trend line of these growths within the twenty years period.

The time series trend lines also indicate that the relative prices of plant oils are cheaper than the animal sources of fats (Figure 6). So, there may be some possibilities of increased demand of plant oils because of the price effects and substitution effects in the demand among plant sources and animal sources of fats.

\section{Where Is Nepal in the Economic Transition within the Nutrition Transition Framework?}

The national income of Nepal increased over the past four decades. The GDP of Nepal has shown an annual increase at a rate of 3.92 per cent between 1970 and 2010. The population has also grown rapidly at a rate of 2.33 per cent per annum. The overall GDP per capita (at constant US \$2005) was 145 in 1970 and increased to 269 in 
Table 3. Patterns of the economic transition (highlighted block in the Popkin’s Framework).

\begin{tabular}{|c|c|c|c|c|c|}
\hline $\begin{array}{l}\text { Patterns/ } \\
\text { variables }\end{array}$ & $\begin{array}{l}\text { Pattern I: } \\
\text { collecting food }\end{array}$ & $\begin{array}{l}\text { Pattern II: } \\
\text { famine }\end{array}$ & $\begin{array}{l}\text { Pattern III: } \\
\text { receding famine }\end{array}$ & $\begin{array}{l}\text { Pattern IV: } \\
\text { degenerative diseases }\end{array}$ & $\begin{array}{l}\text { Pattern V: } \\
\text { behavioral change }\end{array}$ \\
\hline Income & $\begin{array}{l}\text { Survival from } \\
\text { hunting }\end{array}$ & $\begin{array}{l}\text { Subsistence in agriculture } \\
\text { and livestock }\end{array}$ & $\begin{array}{l}\text { Industrialisation and } \\
\text { industrial employment }\end{array}$ & $\begin{array}{l}\text { Emergence of services } \\
\text { sectors and income rises }\end{array}$ & $\begin{array}{l}\text { Income slows but } \\
\text { disparity deceases }\end{array}$ \\
\hline Economy & Hunter-gatherers & $\begin{array}{l}\text { Agriculture and animal } \\
\text { husbandry }\end{array}$ & $\begin{array}{l}\text { Agricultural revolution } \\
\text { (crops rotation; use of } \\
\text { pesticides fertilizers and } \\
\text { technology) }\end{array}$ & $\begin{array}{l}\text { Expansion of Industrial } \\
\text { sectors; and emergence } \\
\text { of services sectors }\end{array}$ & $\begin{array}{l}\text { Promotion of leisure } \\
\text { time physical } \\
\text { activities; and worker's } \\
\text { efficiency and } \\
\text { productivity rises }\end{array}$ \\
\hline $\begin{array}{l}\text { Relative } \\
\text { prices }\end{array}$ & $\begin{array}{l}\text { Barter system, no } \\
\text { role of prices }\end{array}$ & $\begin{array}{l}\text { Role of mediators/ brokers } \\
\text { in the small markets is } \\
\text { influential than the prices }\end{array}$ & $\begin{array}{l}\text { Demand and supply of } \\
\text { foods and livestock within } \\
\text { the country plumps the } \\
\text { prices of plants oils and } \\
\text { animal fats }\end{array}$ & $\begin{array}{l}\text { Agricultural trade } \\
\text { liberalization stimulates } \\
\text { downward pressure on } \\
\text { plants oils and animal } \\
\text { fats }\end{array}$ & $\begin{array}{l}\text { Multinational food } \\
\text { companies control the } \\
\text { supply and prices of } \\
\text { differentiated brands of } \\
\text { foods. }\end{array}$ \\
\hline
\end{tabular}

2010, at an annual growth rate of 1.55 per cent. The Agriculture Sector (value added in constant US dollar) has expanded by an annual growth rate of 2.61 per cent whereas Industry and Services sectors (value added in constant US dollar) have expanded by an annual rate of 5.44 per cent and 5.04 per cent respectively. Agricultural trade liberalization has induced plant fats supply and created downward pressure on plants oils. Tourism has also transferred the taste and preferences of western foods to tourist destinations and urban centres.

Nepal's position in the economic transition has been identified by using Popkin's framework which is scaled from Pattern I to Pattern V (Table 3). The time series trends indicated that new patterns of economic transition have been observed during 1995-2010, which is similar to the pattern IV of the Nutrition Transition as described by Popkin. Popkin suggests a country with economy moving away from agriculture towards industry sectors; increasing national income, participation agricultural trade liberalization and growing urbanisation are considered as Pattern IV in the economic transition.

The implications of economic transition are normally accompanied by improvements in a country's food/nutrition supply and the gradual elimination of dietary deficiencies, thus improving the overall nutritional status of the country's population. The economic and technological developments may also bring about improved quality in the production, processing, distribution and marketing of foods including some negative health consequences related to excess consumption of fat, sugar and process foods.

\section{References}

ADB (2009). Nepal: Critical Development Constraint, Country Diagnostic Studies. Manila: Asian Development Bank. ADB (Asian Development Bank) (1997). Emerging Asia. Manila: ADB.

Bloom, D. E., \& Williamson, J. G. (1998). Demographic Transition and Economic Miracles in Emerging Asia. World Bank Economic Review, 12, 419-455. http://dx.doi.org/10.1093/wber/12.3.419

Bloom, D. E., \& Canning, D. (1999). From Demographic Lift to Economic Lift-Off: The Case of Egypt. Prospects for Egypt Conference, Cairo, Egypt, 3-4 February 1999, 12.

Bloom, D. E., \& Sachs, J. (1998). Geography, Demography, and Economic Growth in Africa. Economic Activity, 2 , $207-273$. http://dx.doi.org/10.2307/2534695

Bloom, D. E., \& Freeman, R. B. (1986). The Effects of Rapid Population Growth on Labour Supply and Employment in Developing Countries. Population and Development Review, 12, 381-414. http://dx.doi.org/10.2307/1973216

Bloom, D. E., Canning, D., \& Rosenberg, L. (2010). Population Aging and Economic Growth in South Asia. Harvard Program on the Global Demography of Aging, Working Paper No. 67

Cwiertka, K., \& Walraven, B. (2002). Asian Food: The Global and the Local. Richmond, VA: Curzon Press Ltd.

FAO (Food and Agricultural Organization) (2010). Economic Growth Hunger and Malnutrition. The State of Food Security in the World, Rome: FAO Press.

Judith, B., Bloom, D. E., \& Rosenberg, L. (2011). Population Aging and Economic Growth in China. PGDA Working Paper No. 53. http://www.hsph.harvard.edu/pgda/working.htm

Krugman, P. (1994). The Myth of Asia’s Miracle. Foreign Affairs, 73, 62-78. http://dx.doi.org/10.2307/20046929

Lang, T. (1999). Diet, Health and Globalization: Five Key Questions. Proceedings of the Nutrition Society, 58, 335-343. 
http://dx.doi.org/10.1017/S0029665199000452

NPC/N (National Planning Commission) (2010). Five Year Plan. Nepal, Kathmandu: NPC.

Popkin, B. M. (1993). Nutrition Patterns and Transitions. Population and Development Review, 19, 138-157. http://dx.doi.org/10.2307/2938388

Popkin, B. M. (2001). Nutrition in Transition: The Changing Global Nutrition Challenge. Asia Pacific Journal of Clinical Nutrition, 10, S13-S18. http://dx.doi.org/10.1046/j.1440-6047.2001.0100s1S13.x

Pyakuryal, B., Thapa, Y. B., \& Roy, D. (2005). Trade Liberalization and Food Security in Nepal. International Food Policy Research Institute, MTID Discussion Paper No. 8. http://www.ifpri.org/sites/default/files/publications/mtidp88.pdf

Phillips, P., \& Perron, P. (1988). Testing for a Unit Root in Time Series Regression. Biometrica, 75, 335-346. http://dx.doi.org/10.1093/biomet/75.2.335

Sachs, J. (2015). The Age of Sustainable Development. New York: Columbia University Press.

UN (United Nations) (2009). World Population Prospects. The 2008 Revision, UN.

WB (World Bank) (1993). The East Asian Miracle: Economic Growth and Public Policy. New York: Oxford University Press.

World Bank (2000). Nepal Country Overview. http://www.worldbank.org

WTTC (World Travel and Tourism Council) (2008). Tourism Satellite Account: Recommended Methodological Framework. London: WTTC.

WTTC (World Travel and Tourism Council) (2013). Travel and Truism: Economic Impact, Nepal. London: WTTC. 